\title{
13 NEO-PENTECOSTAL CHURCHES AND SOCIAL ENGAGEMENT: A CASE STUDY OF THE AZUSA STREET CHILDREN'S PROJECT
}

\author{
John G. Esubonteng ${ }^{1}$
}

\section{INTRODUCTION}

Amongst the hordes of people at Kaneshie in Accra was this boy of about twelve years old, dirty, haggard and looking to forage a living by carrying the rubbish (borla) of a woman selling tomatoes to the rubbish skip already overflowing with waste. ${ }^{2}$ Komla, as his name was, should have been flourishing in school like most boys his age, but instead he was trying hard to scrape a living on the streets of Accra. He was from a dysfunctional family background and had had to leave home. Close by was a young girl with a battered pan on her side calling out to a lady (madam) passing by to be allowed to carry her shopping load. Amina was her name, but she is functionally called "Kaya Yoo". ${ }^{3}$ Komla and Amina are street children and form part of an increasing growing problem of "streetism" in Accra. They spent their time on the street, work on it and live the culture of the street. They are described differently by various people and in this chapter under the general description "streetism", but the terms "street children" or "street kid" will be used interchangeably to describe them. ${ }^{4}$ Living as a street kid is difficult and is known to have calamitous repercussion to both the child and society.

It is in reaction to this unfortunate context that the interventions of Azusa Street Children's Project (Azusa), a neo-Pentecostal charismatic church outfit, emerged. ${ }^{5}$ This chapter will define "streetism", describing its nature and importance in the Ghanaian context, as well as its relationship with human flourishing. By employing empirical evidence, Azusa's intervention in streetism will be discussed and argued to be a legitimate and effective positive social response in a growing milieu of neo-Pentecostal social engagement.

1 Department for the Study of Religion, University of Ghana, Legon.

2 Shanahan P. 2003. "Streets versus Elites: Tensions, Trade-offs, and Treaties with Street Children in Accra, Ghana", Children, Youth and Environments 13(1):361.

3 Coe C. 2012. "Representing Youth: School Dramas and Youth Authority in Ghana", in Ensor MO (ed). African Childhoods: Education, Development, Peace building, and the Youngest Continent. New York: Palgrave Macmillan, 136.

4 Shanahan, "Streets versus Elites", 362.

5 Tettegah CAN. 2012. "Streetism" or Living in the Street, an Emerging Phenomenon As a Way of Life in Developing Countries, a Case Study of Children Living on the Streets of Ghana, PhD Diss, University of Nottingham, 219. 


\section{STREETISM: A DEFINITION}

The definition of "streetism" has been difficult, as the social and economic constructs that lead to this phenomenon vary from place to place. For example, there are differences between the meaning of the term in African and Latin American contexts. ${ }^{6}$ The terminology does not even exist in Britain. ${ }^{7}$ Most authors try to explain streetism by indexing characteristics, such as hunger, poverty, crime, being socially under-privileged and living and working on the street. ${ }^{8}$ Some of these conditions are both cause and perpetuate the phenomenon. Streetism therefore constitutes a coping response. ${ }^{9}$ Christine Tettegah a researcher, has confirmed that street children in Accra were both male and female and were either school dropouts or people who had never been to school. ${ }^{10}$

Some experts also differentiate between children on the street, children of the street and children for the street. ${ }^{11}$ In this connection, Patrick Shanahan, a priest and researcher, has offered this explanation for these two types of children on the streets of most capital cities in Africa. First, there are those who have family close by the urban area and may either rely on them for support or go back home after work. They go on to the streets every day and are known as children on the street. The second category, children of the street, have their total social engagement on the streets. They were probably born there, live there and work there. They may not have any relationship with their biological families - the street is their family. There is, however, a new and shadowy category that is being talked about in Africa - children for the street. These are children born in slums and other socially depraved areas who ultimately become street children. ${ }^{12}$ Thus, street children like Komla and Amina who sleep on the street, experience the vagaries of the weather, the discomfort of mosquito bites, the possibility of rape at night, as well as the theft of their monies during deep slumber. ${ }^{13}$

It is not only the terminology that describe the phenomenon of street children or street child that is embroiled in difficulty. The specifics of streetism as a lived experience are as diverse as they are complex, yet with some identifying commonalities. ${ }^{14}$ The age

6 Ennew J. 2003. "Some Reflections on 'Street Children' in Africa", Children, Youth and Environments 13(1):81-104.

7 Frost N. 2005. Child Welfare: Major Themes in Health and Social Welfare. London: Taylor \& Francis, 297.

Frost, Child Welfare, 298.

9 Hailu D. 2015. “The Composite and Dynamic Risks and Vulnerabilities of Ethiopian Children: The Case of Children in Addis Ababa", Ethiopia Journal of Human Development and Capabilities 16(2):200-219.

10 Tettegah, "Streetism", 64, 77, 84.

11 Sandell R. 2002. Museums, Society, Inequality. London: Routledge, 177.

12 Shanahan P. 1998. "The Alternative Africa", White Fathers-White Sisters 34:14-15.

13 Shanahan, "The Alternative Africa".

14 Africa Institute of South Africa. 1996. Africa Insight. Pretoria: Africa Institute of South Africa, 252. 
bracket of street children in Ghana ranges from birth to 18 years, when the legal definition of a child reaches its limit. ${ }^{15}$ Consequently, street children play different roles in relation their ages. ${ }^{16}$ Infants born on the streets to street parents require protection and care. While children and youth are exploited and sponsoring adults rule the streets. Sexual differentiation is also at the heart of the types of work done. By virtue of their physiques, boys like Komla were more likely to use their strength to earn money by pushing trucks, lifting loads and similar labour ${ }^{17}$ Girls like Amina earn money as head porters or through sexual work. In this connection, social science researcher Georgina Yaa Oduro characterises females who voluntarily engage in sex work as "sexual citizens", who become open to different types of danger, including the possibility of attracting mortal diseases like HIV/AIDS. ${ }^{18}$ These differences in activities are reinforced by the particular business done in the territories, where street children operate. These can reflect as differences in earning ability and job opportunities. ${ }^{19}$

\section{A RAPIDLY INCREASING PHENOMENON}

Streetism, as a phenomenon, has been rapidly increasing in Ghana despite interventions by several non-governmental organisations (NGOs), such as the Catholic Action for Street Children (CAS), Street Aid Girls (SAG) and the Azusa Street Children's Project. Of course, the government through organs such as the Department of Social Welfare (DSW) and Ministry of Women and Children's Affairs (MOWCA) is the principal intervener - albeit ineffectively. ${ }^{20}$ This has created a response gap, which makes NGOs activities not only relevant, but critical. NGOs have sought to prevent the abuse of street children and improve their situation on the streets. ${ }^{21}$ Nonetheless, some suspicions remain over NGO activities, which are characterised as fraudulent in the face of weak governmental supervision. ${ }^{22}$ Nevertheless, there are many NGOs, including faith-based ones such as Azusa, that are genuine.

Catholic Action for Street Children. 2003. The Ghanaian Street Child. Accra: CAS-Ghana, 8-75. Beall J. 1997. A City for All: Valuing Difference and Working with Diversity. London: Zed Books, 73.

Tettegah, "Streetism", 176.

Oduro GY. 2012. "Children of the street: sexual citizenship and the unprotected lives of Ghanaian street youth", Comparative Education 48(1):41-56.

Kilbride K, Suda CA and Njeru EHN. 2001. Street Children in Kenya: Voices of Children in Search of a Childhood. Westport, CT: Greenwood Publishing Group, 96.

20 Tettegah, "Streetism", 106.

Ofosu-Appiah B. 2008. "Ghana: Rejuvenate Non State Actors, Civil Society and NGO's", Africa News, August.

22 Ofosu-Appiah, "Ghana: Rejuvenate Non State Actors". 
In 1992, the CAS estimated that there were 4,000 street children, 10,600 in 1996 and 20,000 in 2002. ${ }^{23}$ A census between 2007 and 2011, conducted by a consortium consisting of CAS and SAG, DSW and Ricerca e Cooperazione (RC) of Italy, recorded a total of 61,492 street children in the Greater Accra Region, indicating a steep and alarming rise in numbers. There were $43 \%$ males and females $57 \%{ }^{24}$ While it is generally accepted that males easily find their way onto the streets, this research ratio was contrary to international trends. Males from all parts of the country find themselves on the street accidentally or incidentally because of personal and familial difficulties. On the other hand, the female population was principally driven by the Kayayei phenomenon, which involves girls who migrate from the Savannah belts of Togo, Burkina Faso and Northern Ghana to Accra in search or greener pastures as head porters. ${ }^{25}$ The name Kayayei is an amalgam of kaya which means "porter" in Hausa, and yoo (plural yei) which means "female" in the indigenous Ga language of Accra. As a sub-culture, Kayayei maintain to a large extent their cultural identity in the amorphous and heterogeneous conditions of the street. ${ }^{26}$ They do this by walking and sleeping in groups as a way of selfpreservation and keeping focus. Many Kayayei are in the more prosperous city of Accra to accumulate business capital, or find professional items, such as sewing machines, needed to learn a trade. The expectation is that the girls should return to their communities when they have achieved this goal. ${ }^{27}$ Others, as may be predicted, never return, ${ }^{28}$ but instead use streetism as a means of permanent income. ${ }^{29}$ Their presence in Accra, therefore, is driven by deep social and economic philosophies, which will continue to produce street girls until prevailing conditions change in their areas of provenance. ${ }^{30}$ The successful operation of females on the tough streets is explained by psychologist Macalane Junel Malindi, who postulates that female street children are resilient due to their ability to adopt and adapt to practices that help them support one another in their difficult circumstances. ${ }^{31}$

23 Catholic Action for Street Children, Ghanaian Street Child.

24 Department of Social Welfare et al. 2011. "Census on Street Children in the Greater Accra". Accra Region, Ghana: Department of Social Welfare and Ricerca e Cooperazione, 1-2.

25 Opare JA. 2003. "Kayayei: The Women Head Porters of Southern", Ghana Journal of Social Development in Africa 18(2):34.

26 Anarfi J et al. 2005. "A Better Understanding of How Life Is", in Voices of Child Migrants. Accra: Development Research Centre on Migration, Globalization and Poverty, 14-18.

Opare, "Kayayei", 42.

29 Mickelson RA. 2000. Children on the Streets of the Americas: Homelessness, Education, and Globalization in the United States, Brazil, and Cuba. London: Routledge, 29.

30 Conversations with different Kayayei revealed that they send the things they buy home as unaccompanied cargo to their home towns. These goodies mount pressure back home who are enticed or forced by their families to come to Accra's "Eldorado". In the case of Adisa Seidu, being a Kaya Yoo helps her look after her kids back home with her parents, who she remits regularly through mobile money transfers.

31 Malindi MJ. 2012. "Positive Psychology: The roots of resilience among female street involved children in South Africa", International Journal of Psychology 47(supl):623-624. 
Similarly, psychiatrist Vikram Patel reports that street children suffer a number of physical health diseases, including skin infections, diarrhoea and venereal diseases caused by poor hygiene and reckless sexual activity, which may also result in teenage pregnancy. ${ }^{32}$ They miss the comfort of loving families and are more prone to having mental health problems, due to the stressful situations in the homes they have left behind and the challenge of making a living on the street. Not surprisingly, therefore, some street kids have atypical emotional composition, with serious developmental deficits, since they live in an environment where little attention is paid to them..$^{33}$ It is not surprising that, Komla, like other street kids, has ended up having brushes with the law and may end up in jail. ${ }^{34}$ His lifestyle has exposed him to drugs and he is a potential HIV/AIDS victim.

These negative characterisations have been criticised by Catholic priest Patrick Shanahan, who designates them as discriminatory and patronising. The street itself he argues has a life, and those who live on it adopt its culture. Their presence is legitimate because of causal factors and the need to be respected and appreciated. ${ }^{35}$ Arnon Bar-On, a writer on streetism, similarly charges that some street children are not delinquents, but earn good money for themselves and their families. He contends that some researchers refuse or fail to accurately report their true findings that indicate some positive aspects of streetism. Instead, they choose to highlight negative stereotypes in consonance with popular thinking or their predetermined ideas. ${ }^{36}$ Likewise, social geographer Tatek Abebe points to the overuse of pity and sympathy for orphans and underprivileged, which masks their hard work to support their families, which any poor family needs for survival. ${ }^{37}$ Streetism can then be understood, generally, as presenting a genuine response to societal conditions imposed on street child. These advocative positions notwithstanding, street kids have needed different social interventions, as NGOs like CAS, Street Girls Aid (SGA), Azusa and others have shown.

\section{STREETISM AND HUMAN FLOURISHING}

Obviously, streetism, as described above, is the product of human corruption and not conducive to its flourishing. The usual idea of corruption today relates to the failings of governments, their officials and laws to guide the public purse, take

32 Patel V. 2003. Where There Is No Psychiatrist: A Mental Health Care Manual. London: RCPsych Publications, 97.

33 Patel, Where There Is No Psychologist, 56.

Lugalla J and Kibassa CG. 2003. Urban Life and Street Children's Health: Children's Accounts of Urban Hardships and Violence in Tanzania. London: LIT Verlag Berlin-Hamburg-Münster, 18. Shanahan, "Elites Trade Off", 360-364. Forum 27(3):201-205. affected Children in Africa”, Geography Compass 4(5):460-474. 
good decisions and protect the weak and vulnerable in society. ${ }^{38}$ It is cogent to consider the philosophical and foundational definitions of corruption, defined as encompassing wrongful destruction, pollution, alteration and misuse of anything, be it an idea or object, intangible or tangible. ${ }^{39}$ Corruption is therefore, contextually, the negative diversion of the intended purpose of human flourishing, in general, but particularly in the lives of some young people leading to streetism. In this thinking, there has been a long string of human corruption in Ghana for centuries. Corruption, as reflected by the daily weaknesses, ignorance, omissions and commissions of life, is universally related to frailties of human nature. ${ }^{40}$ This manifests itself in the form of Ghanaians maltreating other Ghanaians as a way of life. In particular, the various failings of parents, families, broken homes, governments, schools and other institutions that lead to poverty and misery have promoted the corruption of streetism.

Corruption is not only due to failings and weaknesses of some people. Sometimes, corruption that contradicts human flourishing is premeditated, with the agenda of producing poverty and confusion. In Ghana for example, there is a legacy of colonialism in which the coloniser, in seeking to hold social and economic advantage, introduced policies and practices that led to formal deliberate governmental corrupt practices. This unfortunate story has been continued by international forces operating in the neocolonial space, who have deliberately, but clandestinely, perpetuated their advantages by methods which have translated into human corruption and human poverty within less developed countries. ${ }^{41}$ Locally, there is the operation of national political and economic corruption, imposed on Ghanaians by those who get the opportunity to serve the country in different capacities. These range, for instance, from the ordinary carpenter who would divert the wood needed for classroom chairs to the actions of the big politician who considers national funds as a loot to selfishly and lustfully spirit away. The cumulative effects of these inadvertent and advertent incidences of corruption weave an intricate and complex state of corruption within Ghana. These debilitate human flourishing, producing in its wake incalculable suffering, which includes streetism.

Human flourishing has continued to have ever-expanding contextual and applicative meanings, since Plato first described it as eudaimonia, a state of happiness. Thus, the English language scholar Kim Trainor summarising philosopher Martha Nussbaum's thoughts on human flourishing, identifies ten important components, which include, the right to a full life, good health, bodily integrity in safety, and

38 Rose J. 2018. “The Meaning of Corruption: Testing the Coherence and Adequacy of Corruption Definitions", Public Integrity 20(3):220-233. Online at: https://www.tandfonline. com/doi/abs/10.1080/10999922.2017.1397999

39 Dion M. 2010. "What Is Corruption Corrupting? A Philosophical Viewpoint", Journal of Money Laundering Control 13(1):45-54.

40 McGrath AE. 2011. “Frailty and Flourishing", Practical Theology 4(3):315-331.

41 Mwambazambi K and Banza AK. 2014. “Developing Transformational Leadership for Sub-Saharan Africa: Essential Missiological Considerations for Church Workers", Verbum et Ecclesia 35(1):1-2. 
the ability to use one's senses, thoughts and imagination. ${ }^{42}$ In addition, one should flourish by having the freedom to express emotions, affiliate, reason, control one's environment, play and relate to others socially. ${ }^{43}$ The actual need and application of these basic components in practice vary with individual circumstances, leading the academic Louis Tay and his research colleagues to propose that human flourishing has so many different influencing conditions that it may be difficult to measure by definite simple and single mechanisms. It was therefore more effective to consider flourishing from the viewpoint of types and outcomes, benefits and extents. ${ }^{44}$ It is easy, though, to frustratingly condemn the inexactitudes of what human flourishing is to an unattainable utopia whose search then becomes elusive. Yet the academic Richard Langer and his co-authors aptly capture the essence of human flourishing in its simplicity. Humans flourishing, they contend, is practically a shared experience and marked by a communality of thoughts and deeds. When people fully express "the most distinctive features of human nature" in ways that they enjoy together with others, such as having good, personal relationships, food, shelter, education and other goods, then they are prospering. This, of course, is achieved through the right decisions and actions both from within and without the individual. ${ }^{45}$ Fortunately, the human spirit in general persists, despite its frailties, to aspire to and work towards the prosperity of its race through innumerable means, including education, use of law, industry, religion, and other institutions.

Obviously, the negativities of streetism run contrary to the best practices of human flourishing. Children like Komla and Amina have missed their childhood working the streets. They have been forced by poverty and other harsh conditions sometimes to make choices they would not enjoy and which are indicative of a lack of flourishing. Indeed, streetism can be imagined implicatively and effectually as producing a form of mental and physical disability amongst street kids, individually and socially, in relating to society. ${ }^{46}$ It is these difficulties confronting street kids that have drawn compassion and intervention from many an NGO, including faith-based ones.

\section{NEO-PENTECOSTALISM AND STREETISM}

The idea that religious tools should be used by a neo-Pentecostal or charismatic church to intervene in streetism certainly elicited both suspicion and disapproval from secular sources. Jessica Rose, a health counsellor, points out that the current

42 Trainor K. 2005. “'What Her Soul Could Imagine': Envisioning Human Flourishing in Marge Piercy's Woman on the Edge of Time", Contemporary Justice Review 8(1):25-38.

Whitt JD. 2016. "In the Image of God: Receiving Children with Special Needs", Review $\mathcal{E}$ Expositor 113(2):205-216.

44 Tay L, Pawelski JO and Keith MG. 2018. "The Role of the Arts and Humanities in Human Flourishing: A Conceptual Model", The Journal of Positive Psychology 13(3):215-225.

Whitt, "In the Image of God". 
secular use of psychology omits religion. ${ }^{47}$ More radically, researcher Isaac Arthur considers religious intervention in streetism in Ghana as a non-starter, as these children have neither the means nor time to attend church services. ${ }^{48} \mathrm{He}$ argues that even where street children have been involved with organisations purporting to help them, they were sometimes wrongly indoctrinated and abused. ${ }^{49}$ There is also the case that religious groups offering social interventions discriminate in favour of those who agree to participate in their activities and possibly against those who do not. ${ }^{50}$ Nevertheless, religious intervention in streetism in Ghana not only continues to be offered, but has been clamoured for. ${ }^{51}$

In his foreword to the book Pentecostalism and Development, Norman Long, an expert in Pentecostalism, suggests the possibility that neo-Pentecostal movements could fill the lacuna created by the present moribund status of the global Social Gospel movement and the loss of the influence of liberation theology. ${ }^{52}$ His justification is that the biblical basis on which Pentecostal groups work encapsulates both ideologies. Similarly, pastor and academic Hugh Bair provides a blueprint by which these neo-Pentecostal NGOs can interact with those they help pastorally. He thinks progressive Pentecostals should focus vertically on the issues of salvation and social transformation and horizontally on demonstrating the works of Christ such as expressing love. ${ }^{53}$ In the pursuit of this horizontal agenda, researcher and professor William Kay believes that the testimonies and energies of converts are invaluable. Specifically, Kay observes, "The activism and energy of Pentecostals may be stimulated by the narratives of their own lives (if they have been 'saved' from crime or addiction) or by reading the gospels with fresh eyes." ${ }^{54}$ The above confirms the merits of the use of testimonies of answered prayers by Pentecostals, which is promoted by some faith-based NGOs. ${ }^{55}$ Indeed, the use of prayer in helping assuage or change the circumstances of people has long been widely recognised

47 Rose J. 2005. "Pastoral and Counselling and Prayer", in Gordon Lynch J (ed). Clinical Counselling in Context series: Clinical Counselling in Pastoral Settings. London: Taylor and Francis, 41-42.

48 Arthur II. 2013. "Streetism": A Socio-Cultural and Pastoral Theological Study of a Problem in Ghana. Bloomington, IN: AuthorHouse, 113-114.

49 Aptekar L and Stoecklin D. 2014. Street Children and Homeless Youth: A Cross-Cultural Perspective. Dordrecht: Springer, 186.

50 Kilbride PL et al. 2000. Street Children in Kenya: Voices of Children in Search of a Childhood. Westport, CT: Bergin \& Garvey, 140.

51 Quampah D. 2014. Good Pastors, Bad Pastors: Pentecostal Ministerial Ethics in Ghana. Eugene, OR: Wipf \& Stock, 182.

52 Long N. 2012. "Foreword", in Freeman D (ed). Pentecostalism and Development: Churches, NGOs and Social Change in Africa. New York: Palgrave Macmillan, 217.

53 Bair H. 2012. "Pastoring a Pentecostal Church", in Whitt RK and Arrington FL (eds). Issues in Contemporary Pentecostalism. Cleveland: Pathway Press, 25.

54 Kay WK. 2009. Pentecostalism. London: SCM Press, 303.

55 Hollenweger WJ. 2004. "An Introduction to Pentecostalisms", Journal of Beliefs $\mathcal{E}$ Values: Studies in Religion \& Education 25(2):125-137. 
in Christianity and also by those involved in social work. This may not be fully acceptable by all those who need help. Alcohol Anonymous, for example, reported a mixed reaction to prayer it promoted during its meetings: "We heard covering clients state that prayer made them feel more comfortable with the programme. Others stated that they were uncomfortable because of the 'God thing'." 56 These objections, however, have not discouraged Christian counsellors, who routinely use prayer, claiming its benefits outweigh its weaknesses as was done at Azusa. ${ }^{57}$

It is important to emphasise why the involvement of neo-Pentecostals in social engagement is important. Traditionally, Pentecostals have concentrated on otherworldly values of salvation, miracles and holiness, to the extent that they have been less involved in the mission of meeting people's physical needs. Consequently, theologians Donald E Miller and Tetsunao Yamomori have in the last few years reported a consistent shift in emphasis amongst neo-Pentecostals who engage in social interventions. ${ }^{58}$ In Ghana, this shift has partly been driven by the continuous need of neo-Pentecostal outfits to look like and behave like churches in showing love and obedience to Christ. In different ways, they desire a deeper level of socio-cultural insertion, such as the Traditional Missionary Churches (TMCs) have had. In fact, the picture of what a church was had been formulated by the existing TMCs, which as part of their ministries built schools, hospitals and other institutions, in pursuance of their missionary engagement with society. ${ }^{59}$ Therefore, neo-Pentecostal churches, whose emergence dates to the late 1970s have needed to launch this-worldly missions, which met people's physical needs but which also afforded them the image of legitimate caring churches.

It is becoming evident, in their formative years, that these younger neo-Pentecostal churches unlike the older Pentecostal ones did not participate much in social services for reasons of numerical and financial incapacity, amongst others. Numerically, these churches were small and did not possess the diversity of personnel who could initiate and carry out social services. These small churches also often lacked the financial wherewithal to extend themselves beyond their churches' needs. As these churches have grown financially, they have been involved progressively in various social welfare activities in the areas of health, education, care for the elderly, orphanage work and other services. It is within this context that the Azusa Street Children's Project operated as a Pentecostal non-governmental organisation intervening in streetism.

56 Vick D and Roades E. 2010. Drugs and Alcohol in the 21st Century: Theory, Behavior, and Policy. Burlington, MA: Jones \& Bartlett Learning, 302.

57 Rose, Pastoral Care, 42-46.

58 Miller DE and Yamamori T. 2007. Global Pentecostalism: The New Face of Christian Social Engagement. Berkeley, CA: University of California Press.

59 Atiemo AO. 2007. "The Evangelical Christian Fellowships and the Charismatization of Ghanaian Christianity", Ghana Bulletin of Theology 2:43-65. 


\section{AZUSA STREET CHILDREN'S PROJECT}

Destiny Transformation Centre (DTC), the umbrella organisation for the Azusa Street Children's Project is a Ghanaian, neo-Pentecostal or charismatic church founded in 1992 by Rev Godsaye Ebow Simpson, who also doubles as the founder and visionary for Azusa. ${ }^{60}$ True to its neo-Pentecostal theology, DTC practises glossolalia and believes in healing, miracles and a real God, who positively intervenes in the lives of people. ${ }^{61}$ It adheres to a variant of the prosperity and wealth gospel that emphasises personal integrity, Christian responsibility and faithfulness within the moorings of Ghanaian culture. Though neo-Pentecostals have been charged with being consumerist, centripetal in outlook and believing primarily in the amassing of personal and organisational wealth, ${ }^{62}$ DTC is socially centrifugal. ${ }^{63}$ It has addressed the concerns of the needy in society through Azusa and has given to the poor and vulnerable on the streets of Accra.

The name Azusa Street is reminiscent of the origins of Pentecostalism in 1906, a period of revival, fervency of spirit, glossolalia and Christian racial integration, which was made practically possible at the period in the United States by operation of the Holy Spirit. ${ }^{64}$ These expressive values constitute what DTC believes should be happening to street children like Komla. Thus, stigmatised street children are welcomed to share a common platform of worship with those who were more privileged in society in the process breaking down social barriers. Their interactions create further synergies between people where help was extended on individual basis. Azusa therefore offers a practical social intervention in the difficult phenomenon of streetism from a faith-based perspective. ${ }^{65}$ Azusa's goals include bringing salvation and transformation to the child in the sense that the child could get off the street and continue normal life in the home environment, where possible. In the event that the children would remain on the street - a reality produced by the difficulties in homes from which they come - the child works the street, but kept away from crimes and other vices.

The research information on Azusa for this chapter was obtained qualitatively through interviews with the DTC senior pastor, Rev Godsaye Ebow Simpson, the pastor in charge of Azusa, Rev Alex George Sagoe and other Azusa workers. The research included participant observation in the project, which included attending

60 The write-up on Azusa Street Children Project is a combination of information from its brochure, personal action as an observer participant, and an interview with pastor Alex George Sagoe, director of the Project, by J Esubonteng, Accra, 2008 and 2015.

61 Asamoah-Gyadu JK. 2000. African Charismatics Current Developments within Independent Indigenous Pentecostalism in Ghana. Leiden: Brill, 165.

62 Gaiya MAB. 2015. "Charismatic and Pentecostal Social Orientations in Nigeria", Nova Religio: The Journal of Alternative and Emergent Religions 18(3):63-79.

63 Gaiya, "Charismatic and Pentecostal Social Orientations in Nigeria".

64 Hollenweger, "An Introduction to Pentecostalisms".

65 Gaiya, "Charismatic and Pentecostal Social Orientations in Nigeria". 
services and interacting with the street children between 2008 and $2015 .{ }^{66}$ A mixture of theological and historical tools formed the data analysis framework of electronically recorded interviews and written observations. ${ }^{67}$ In 2015, those who run Azusa took measures which fundamentally altered the way it operated. Essentially, members of the street children congregation merged with the regular church. This decision figures into the instant research, because it effectively altered the uniqueness of this work in ways that will be discussed below. It would be fair to assess that this new decision summarily curtailed Azusa's effectiveness. Notwithstanding this outcome, the research observations and lessons remain useful.

In fact, the effectiveness of Azusa ministry has been corroborated by Tettegah, who reported in her doctoral research that children on the streets told her about the help they received from Azusa and further recommended that she interacted with the ministry. ${ }^{68}$ One street girl shared the following observation: "Even my parents sent me to our hometown to my aunt, I heard the voice to steal, so I stole her GH $\$ 60.00$ and ran back to Accra. My parents knew about this because my aunt told them I stole GH $\$ 60.00$. But when I came to the street and started attending this church it stopped. I have not been hearing those voices again and I have never stolen anything again." 69

\section{A CONGREGATION OF STREET KIDS}

From its Protestant Evangelical perspective, Azusa's principal idea behind this work is that a person transformed by the salvific work of Christ is equipped to change by the renewal of his mind, morally and practically. The need to be born again was therefore central to bringing change to street children. ${ }^{70}$ God's power was believed to provide inner strength that made it possible to make lifestyle changes. An environment of preaching, singing, prayer, fellowship, counselling and practical assistance, such as feeding the kids meals, demonstrated this power. ${ }^{71}$ On a typical Sunday morning, pastor Alex George Sagoe, ${ }^{72}$ along with his team made up of current and ex-street kids and church workers, combed the streets around

66 Banke S, Maldonado N and Lacey CH. 2012. "Christian School Leaders and Spirituality", Journal of Research on Christian Education 21:235-264.

Stanford JH, Oates BR and Flores D. 1995. "Women's leadership styles: a heuristic analysis", Women in Management Review 10(2):13; Maier K and Coleman S. 2011. "Who Will Tend the Vine? Pentecostalism, Parenting and the Role of the State in 'London-Lagos'", Journal of Religion in Europe 4(3):455.

68 Tettegah, "Streetism", 80.

69 Tettegah, "Streetism", 162-164.

70 Gifford P. 1994. “Ghana's Charismatic Churches", Journal of Religion in Africa 24(3):241-265.

71 Miller DE and Yamamori T. 2007. Global Pentecostalism: The New Face of Christian Social Engagement. Berkeley, CA: University of California Press, 71-74.

72 Alex George Sagoe is the director of the Azusa Street Children Project, chief counsellor and pastor in charge of the Azusa Street church or congregation. 
Kaneshie in the known sleeping places of these children to invite them to church a little after 6:00 AM. By 7.30 AM, the team returned to the chapel grounds for service in a rented classroom in 2008. In 2015, services took place at the DTC building at Zongo Junction near Kaneshie in Accra. The kids began service with prayer, which continued until they entered a time of praise and worship. There was no coercion or threats to make these children participate; rather, workers appealed to the sense of self-worth and the relationship they built with the children in an environment of love and goodwill. ${ }^{73}$

The Azusa kids usually consisted of more males than females, aged from five years to early twenties. They sauntered into the church - usually unwashed, hair unkempt, dirty clothes and some with sleepy faces. As they prayed in loud voices with typical Ghanaian Pentecostal gesticulations of hands and body, they came alive. In 2010, by the time prayer was over, the room was almost filled containing about 54 to 100 children of all ages. In 2015, however, the numbers had dropped to about 40, because the Azusa church service location at Zongo Junction was a little further from Kaneshie market and thus required transportation. On a particular Sunday, a teenager approaching 20 years of age, who had been helped off the street and was now back in junior high school preached with help from Pastor Alex. The topic was "Holiness and Integrity", during which the young preacher challenged the congregation to do the right things according to the instructions of God. There was more prayer and an altar call after the sermon. The fervency of this worship may appear superficial and insincere. Yet the conversions and changes that occurred in the lives of these children bear great testimony to the effectiveness of the Azusa programme. Children who reported being born again can ultimately join DTC or any other church of their choice and either get off the street or continue on the street as morally and religiously reformed individuals.

It must be noted here that the unusual composition of more males than females as they attended these services was contrary to census trends recorded by Department of Social Welfare, which reported that street girls exceeded boys. ${ }^{74}$ This was probably because most of the female street children were Kayayei and tended to be Muslim or African Traditionalist. They were, therefore, not easily open to attending church services. ${ }^{75}$ In addition, the Kayayei banded together in such a way that it became a challenge to convincing groups of girls and young women to come to church. It appeared, therefore, that Azusa's message had not been able to penetrate the Kayayei groups.

At Azusa services, there were no offerings. Instead, participants were served breakfast of bread, margarine and beverage or porridge after the service by Cassandra and her team, who by 2008 had worked for the church for about 10 years

73 Gifford, "Ghana's Charismatic Churches", 251.

74 Department of Social Welfare et al, "Census on Street Children", 1-2.

75 Anning EK and Abdallah M. 2013. "Islamic Radicalisation and Violence in Ghana", in Gow J, Olonisakin F and Dijxhoorn E. Militancy and Violence in West Africa: Religion, Politics and Radicalisation. Oxon, MD: Routledge, 100. 
as a teenager. ${ }^{76}$ It appeared, during most services, that some of the kids wanted all the talking to be over with so they could come to what was to them the most important part of the service - breakfast. This feeding ethic could be argued against by some who would see it as a form of influence peddling. ${ }^{77}$ There were, however, no strings attached, and those who missed services suffered no recriminations. Pastor Alex emphatically insisted that breakfast should be seen as a practical intervention for Sundays, which were usually financially difficult for some who would not have money to eat because little commercial activity occurred on Sundays to provide them with money. In addition, he believed it was a way of obeying Christ, who taught that feeding the hungry poor was a way of ministering to the Lord himself. ${ }^{78}$ Therefore, Pastor Alex emphasised that though this feeding process might distract the focus of the children from hearing the gospel that was being preached, its value in minimising hunger should not be underestimated.

The Azusa policy of feeding the street kids during services was maintained during DTC conventions, which usually lasted for a few days longer than the usual Sunday and Wednesday Azusa meeting days. During these conventions, the Azusa children were further sensitised to health, legal and crime issues. There were also massive gift bazaars during the church's anniversaries, Christmas and Easter celebrations, where the kids were feted. The only service which did not normally involve feeding was the Wednesday prayer, and teaching meetings during which money and other material assistance were given only to those in need.

\section{WORKING TOWARDS TRANSFORMATION}

As a standard operational practice, street kids who responded to Azusa's message of conversion were trained in prayer and scriptural proficiency so that they could read. The basic belief here was that these spiritual exercises, together with the presence of the Holy Spirit in the lives of converts, provided a basis for practical lifestyle changes over time. Pastor Alex and his team counselled those who came to these services and responded to the altar call. About $10 \%$ of these children usually responded to the preaching this way. There were those who repeatedly came forward to the altar, showing that they had not fully understood the concept of salvation by faith or that their lives on the street required them to perform this weekly confession. Apart from this brief counselling session, elaborate counselling was offered throughout the week, when individuals with issues to be discussed came into the Azusa's Office. Other times, counselling was done on the field.

76 Cassandra Allotey, who believes God has called her to the service of street children, is one of the workers in charge of food at the ASCP church services. In a short interview, she expressed gratitude to God for the opportunity of serve, and believed that God has and continues to bless her because of her service to the street children.

77 Faleye OA. 2013. "Religious Corruption: A Dilemma of the Nigerian State", Journal of Sustainable Development in Africa 15(1):170-185.

78 Webster JS. 2013. "That One Might Not Fall: A New Testament Theology of Food", Interpretation: A Journal of Bible and Theology 67(4):363-373. 
The idea was to work with the wills and minds of these children and treat them like a pastor did his flock. Pastor Alex emphasised that laboriously building relationships of trust with the kids was key to any success. It took a great deal of confidence building before a street child genuinely opened up to the counsellor. This is so, the Catholic researcher and priest, Shanahan argues, because the street children find others to be elitist who should not be trusted. Shanahan further advocates the need for complete unconditional acceptance and respect for the street child for the purpose of effective ministry. ${ }^{79}$ In any case, those street kids who responded to counselling consistently and decisively were observed by Azusa workers over time and then given closer attention and absorbed into DTC or encouraged to attend a good church of their choice.

Here, the markers used as criteria to determine effectiveness of counselling included a consistent positive reflection of a Christian lifestyle and testimony while working and or living on the street. This was easily confirmed by enquiries and conversations with other children. Sometimes, some of the big boys who accepted Azusa's transformational message protected their little "brothers and sisters" on the streets where they would have normally bullied them. Again, the willingness of positively affected children to go back home and be reunited with their families after conversion bore testimony to a changed life. Sometimes, when the family situation was dire, the children were put into a sanctuary within the temple complex of DTC. Another important marker for change was the willingness of some children to get back to school. Here, Azusa responded by providing sponsorship when necessary. It must be understood that the decision to go to school meant the loss of income from street work. Initially, Azusa wanted to support these children through university, but available resources had not been enough to support this desire. Indeed, one former street child sought a medical school admission in 2015, but was unsuccessful. Even in 2018, about two and half years after the project methodology was changed, one of the children extracted from the streets had become a student of the Kwame Nkrumah University of Science and Technology and was pursuing a college degree. In the same vein, others who preferred to learn trades were encouraged to go back home to learn or were seen through trade schools by donor sponsorship facilitated by Azusa where necessary until they finished. Now and then former street children came back for counselling and advice on different issues including those that were work related.

Unfortunately, some of the children relapsed morally and would return to their old street ways. This could be due to unfavourable conditions at home when the children returned from the street or the negative influence of peer pressure. Others simply lost their focus and drive. But the majority of those who responded to Azusa's ministry remained on the street working with a better social ethic.

Shanahan, "Elites and Trade Offs", 360-361. 


\section{PROVIDING MORE SOCIAL SUPPORT}

Azusa offered limited medical and legal support to street children as well. The medical care situation of these kids could be dire. Sometimes, Azusa assisted kids to access health care by paying for the cost. In 2008, a few of the Azusa kids who had registered with National Health Insurance Authority (NHIA) could access health care through the scheme. Nevertheless, most of them were without insurance cover. By 2015, some the children claimed that the reliability of the NHIA scheme as a social intervention was in doubt. Hospitals and pharmacies were refusing NHIA card payments. Nonetheless, the street kids had a generally pragmatic approach to their health needs. As was observed during this research and collaborated by Tettegah, some street kids practised corporate self-help in looking after each other - their own form of "street health insurance". They put the requisite money together to send each other to the hospital as a survival mechanism. ${ }^{80}$ First, this showed that given the right conditions, street kids could help each other. Second, it indicated a common-sense approach to solving problems that made them resilient on the streets. ${ }^{81}$

One important challenge faced by the street kids was their constant brushes with the law. Some of them drifted between crime and work, such as sweeping and carrying people's loads. It was the experience of Pastor Alex that his congregants and even some non-congregants repeatedly requested his intervention in posting bail. He saw these requests as a further opportunity to evangelise. The journey of these children towards attaining full ethical integrity could be long and arduous Pastor Alex noted. Some were easily tempted, even while responding to teachings and counselling. Though I never witnessed this during any of my visits, DTC members interviewed reported, regretfully, that sometimes their items were stolen during church services ostensibly by street children when they had had to come for worship services in the regular church. This constant challenge faced by these young ones continuously emphasised the need for legal support for the Azusa project.

\section{CHALLENGES FACING THE AZUSA PROJECT}

In 2015, the Azusa Project faced one of its most intense financial crunches. This necessitated the development of a new phase of activities aimed at integrating church members and street children quicker than before. Thus, instead of keeping street kids in their own services for a longer period until they became used to church life, they were being integrated much more quickly. This approach had greater challenges and even the risk of failure. Earlier, Azusa had lost its services' premises at Kaneshie and had to bus children to DTC church facilities at Zongo Junction near Kaneshie, putting further financial and logistical burdens on the Azusa Project. There was a hint of exasperation in Pastor Alex's voice as he recounted

80 Tettegah, "Streetism", 150.

81 Malindi, "Female Resilience", 246. 
disappointments with would-be helpers, including DSW. Although Azusa was doing as much as its internal resources could support, there was a shortfall.

It became logical to suppose that if other Christians with similar beliefs and values as those of the DTC contributed finance and personnel, it would be easier to find the means not only to continue the work, but also to expand it. Consequently, additional interviews were conducted with other neo-Pentecostals outside DTC to provide the insights into that possibility. It was principally discovered that there was a lack of sensitivity to and knowledge of streetism. Some of the people had stereotyped images of the street children, believing they were just kobolo (truant, trickster youth) roaming around by choice. ${ }^{82}$ They did not understand streetism enough to want to donate towards it. ${ }^{83}$ Again, contrary to the neo-Pentecostal ethic of mediatisation, the effort in drawing attention to Azusa's work in the past had been limited, which in turn had affected its possible resource base. In a random sampling of neo-Pentecostals who were members of twenty different churches around the Azusa Project's location, only a few knew about it. This meant that the project could not get much help from other neo-Pentecostals. Even where there was the knowledge of the Azusa Project, a general lingering suspicion of NGOs financial integrity hindered the willingness of people to participate. Worse still, the impression that charismatic churches were supposed to be rich produced more apathetic responses. Some individuals had an unfounded suspicion that charismatic churches were inwardlooking and had to be profiteering and accumulating more money than was being spent. Furthermore, there were those in the Christian community who, as Norman L. Geisler and his co-researchers captured, were too heavenly minded to be of much use to the world around them. ${ }^{84}$ They were sceptical about the practical usefulness of Azusa's intervention. Finally, other persons believed they were contributing to the God's work by participating in what their own churches demanded of them in the form of tithes and offerings. Azusa should contact their church leaders for support.

I believe though, without any scientific data, that one of Azusa's strengths could unexpectedly be having a boomerang effect on its operations. In deciding to allow some its converts and beneficiaries to join other churches, a continuous resource of possible loyal people and the funds they could have brought in was dispersed. There was always the odd possibility that one individual amongst these people could make a financial difference. On a more positive note, it could be argued that the Azusa Project's openness in allowing its products to join other churches could easily make it possible for other people of different churches to participate financially and otherwise.

82 Maxson CL and Klein MW. 1997. Responding to Troubled Youth. New York: Oxford University Press, 185.

83 Kilbride P, Suda C and Njeru E. 2000. Street Children in Kenya: Voices of Children in Search of a Childhood. Westport, CT: Greenwood Publishing Group, 141.

84 Geisler NL, Turek F and Limbaugh D. 2004. I Don't Have Enough Faith to Be an Atheist. Wheaton, IL: Crossway Books, 329. 


\section{TOWARDS A MORE EFFICIENT SOCIAL INTERVENTION}

The success stories of Azusa is told by the changed lives of children who once lived off the streets. There were those who left the streets to their homes. Families have been reunited and children have refocused on their education. For some who remained on the streets, their view of life has been improved and they look forward to achieving something in life in the future because the power of the gospel of Christ and the other services offered by Azusa. These include people like Wisdom Kudiabor and Stephen Pamford, who became part of Azusa team of fieldworkers, and Bright, who was the personal assistant to Pastor Alex. Pastor Emmanuel Mensah, once a street child, has attended a Bible school after passing through the Azusa programme and preaches and thanks God daily for the ministry of Azusa.

Yet, one might ask whether Azusa's work, which was pioneering in many ways within neo-Pentecostalism, has fully accessed the most efficient methodology for caring for the street kids. Here, one can compare Azusa's work with other faithbased organisations such as the CAS. The latter is better known and resourced and has been around longer, since 1992. Though the comparison could be both qualitative and quantitative, a qualitative analysis was chosen for the instant study, because quantitative comparative figures were unavailable and would have required further research. The commonalities between these two organisations were that the aims of CAS and Azusa were similar in that they targeted providing a better life for the street kids while on the street and to counsel with them to the point where they could go back home and possibly earn money differently. Therefore, both Azusa and CAS invested in training and other lifelong opportunities. Actually, they both operated within the inner business districts of Accra and therefore had the same clientele. In fact, some kids enjoyed the services provided by both organisations concurrently. They bathed and played games at CAS facilities and attended Azusa church services for breakfast. These organisations thus complemented each other. ${ }^{85}$

However, in seeking to achieve their goals, Azusa and the CAS employed two different strategies. The CAS, though sponsored by the Catholic Church, relied on practical reasoning and the expertise of social workers from all denominations to achieve its goals. It did not overtly push a Christian agenda, but practically showed an attractive compassion that came from the church and its clergy. ${ }^{86}$ Azusa on the other hand relied on evangelism and the power of God to convert the individual and help break bad habits even in the most difficult of situations. In this approach, faith was expressed evangelically through prayer.$^{87}$ Counselling and other material support undergirded Azusa's work of preaching and teaching. This approach may not meet the approval of secularists like Apollo Rwomire, a sociologist, who contends that individuals and members of professions that care for street children,

85 Interviews with pastor Alex Sagoe, 2008 and 2015.

86 Interview with George Afum Ansah, manager of the CAS facility at Lartebiokorshie, by J Esubonteng, Accra, Ghana, 5 February 2008. The facility is a place where the children can take a bath and play games.

872 Corinthians 5:17. 
whom he classifies as a "liberation movement", needed to move away from the traditional grounds of disapproval of streetism, which included preaching to the kids. He posits the likelihood that a better influence could be exerted on the situation if the people who were concerned would help street children in their liberation. They could both protect the rights and better the position of street children, since the phenomenon is not going to change immediately. ${ }^{88}$ To this, the Azusa Project director, Pastor Alex, countered by insisting they did not look down, disapprove or stigmatise the street children. They rather loved them and encouraged them to do something positive about their situation. He argued that the meals, the counselling and other material provisions were practical means of changing the situation of the street kids.

There was, indeed, further room for Azusa to improve on its service delivery. Its place as one of the pioneering groups in this kind of intervention could be leveraged to attract other people and groups to assist in this type of ministry. With regard to improving quality, Azusa needed to, as was the case of CAS, to engage more trained professionals if that meant the hiring of charismatic Christians for the preservation of its outreach methodology. For, being willing, understanding and having the necessary compassion and enthusiasm alone did not fully qualify one to work with street children on a full-time basis. It was necessary, additionally, for volunteering personnel to acquire the knowledge and competence to handle street kids employing in-house continuous programmes of development.

\section{A GROWING FUTURE PROSPECT}

Though Azusa's contribution to social engagement is effectively over because of the new methodology DTC chose to employ, some of the observations and lessons remain even more relevant for future Pentecostal social engagement. For example, Azusa confirms the point that faith-based solutions continue to be relevant for social needs. The effort and messages of groups like Azusa remain relevant in inspiring change through divine origins. As one of the Azusa's worker's summarised: God is in the business of saving souls and changing lives. His power is relevant today inexplicably to touch people. The practical love that was shared with street children had a way of penetrating the impregnable outer defences of anger, rebellion and the lure of crime these children experienced.

The Azusa project similarly demonstrated a growing activism by neo-Pentecostals who traditionally have had an other-worldly orientation. This should be considered as a welcome development, as more Komlas and Aminas, needing different social interventions, may be successfully aided to become like a Pamford or Pastor Mensah. Currently, Ghanaian Charismatic denominations, such as the International Central Gospel Church (ICGC,) Lighthouse Group of Churches (LGOC), Victory Bible Church (VBCI), Living Streams International (LSI) and others, have initiated

88 Apollo R. 2001. African Women and Children: Crisis and Response. Westport, CT: Greenwood Publishing Group, 198. 
different social interventions as part of their missions and social responsibility activities. ${ }^{89}$ It is a positive fledging trend that is yet to grow to the desired levels of impact. At the present time, two critical observations can be made of neo-Pentecostal social engagement. First, the bigger the church or denomination, the better and larger the extent of its social involvement. Thus, as the churches like ICGC, LGOC, and others have grown into denominations from their initial single congregation status, they have tended to be more socially engaged in different ways, including helping the poor on the streets. Secondly, the older the churches, then the stronger, more diverse and better organised is their social activism. Therefore, the factors of size and longevity can obviously be related to the funding abilities of these neoPentecostal churches. In this analysis, one should expect an increasing trend of neoPentecostal social activism. In relation to Azusa's finances, it could be suggested then that DTC did not perhaps fully grow its financial strength in these two areas before embarking on its social intervention. It operated Azusa as a single congregation. Nevertheless, this argument tumbles in the face of other considerations, such as the pressing needs of street kids in the mid-2000s, as well as directives the church leadership believed they received from God.

One suggested response for funding the needs of smaller neo-Pentecostal churches would be the consideration of a new paradigm of fund raising in which synergies, collaborations and cost sharing could be established between different churches or organisation that hold similar visions. Logically, internal procedures and methods including governance would inevitably need to be remodelled beyond the current simple one in which single churches attempt to solely fund their social work. The main barrier, as theologian Donald E. Miller has earlier predicted, would be the growing inward-looking nature of Pentecostal churches as their denominations grew. ${ }^{90}$ Nevertheless, the evidence of changed lives, reunited families, street children becoming professionals and other successful outcomes, which cannot be contradicted, should make an imperative case for social interventions. These are the lasting social contributions neo-Pentecostal churches can make to the flourishing of their societies here and now, alongside the goal of leading people to heaven.

89 From the websites of ICGC, VBCI UDLOC and other charismatic churches, various social interventions could be appraised. They include education scholarships, feeding the poor, contributions to health and supply the needs of orphans.

90 Miller DE. 2006. "Pentecostalism and Social Transformation", in Hunter HD and Robeck CM (Jr) (eds). The Azusa Street Revival and Its Legacy. Cleveland, TN: Pathway Press, 345. 